Original Paper

\title{
Economic Assessment of Miscanthus Cultivation for Energy Purposes in the Czech Republic
}

\author{
Kamila VÁVROVÁ*1, and Jaroslav KNÁPEK *2 \\ (Received November 29, 2011)
}

The article is focused on the issues of economic evaluation of Miscanthus cultivation on agricultural land in the Czech Republic. The methodology of economic assessment is based on the calculation of minimum production cost - minimum price of heat in EUR/GJ of heat in biomass. The minimum production cost represents the threshold of economic efficiency of production for the investor and its determination utilizes an economic model capturing all processes related to the cultivation of biomass for energy purposes. Miscanthus vegetation is considered for the production of biomass for direct combustion (a so-called spring harvest after the winter). Input data used in the model come from the experimentally collected data from the research plots of Miscanthus and from the market valuation of the individual activities using 2010 prices. The minimum price of Miscanthus varies between 3-12 EUR/GJ (2010 prices) depending on the yields and the date of harvest.

Key Words

Miscanthus, Economic aspects, Biomass production, Minimum price

\section{Introduction}

Biomass is currently the most important renewable energy source (hereinafter only "the RES") in contribution of RES to the primary energy sources (PES) in the Czech Republic. Of the total contribution of RES to PES in 2010 in the amount of $119.2 \mathrm{PJ}$, the share of solid biomass (for burning) was about 69.5\% (82.8 PJ) and of biomass processed in biogas stations about 6.2\% (7.4 PJ). Biomass plays a significant role in the structure of RES used for electricity production. Of the total 5.9 TWh of electricity generated in 2010 based on RES (RES share in 2010 in the gross domestic electricity consumption was thus 8.32\%), 1.49 TWh of electricity was produced based on combustion of solid biomass (25.3\% of RES in total) and 0.63 TWh in the biogas stations ( $10.75 \%$ of RES in total) ${ }^{11}$.

Objectives for development of the use of RES until 2020 are defined in the National Action Plan of the Czech Republic for energy from renewable sources (hereinafter only "the RES NAP"), which was prepared according to the

* 1 Silva Tarouca Research Institute for Landscape and Ornamental Gardening, Publ. Res. Inst.

Kvetnove namesti 391, 25243 Pr?honice, Czech Republic, vavrova@vukoz.cz

* 2 Czech Technical University in Prague, Faculty of Electrical Engineering

Technicka 2, 16627 Prague 6, Czech Republic, knapek@fel.cvut.cz
EU Directive 2009/28. Biomass plays a crucial role in the planned development of the use of RES, which can be documented by an expected increase in the use of biomass for electricity production, as well as by an increase in the absolute and relative contribution of biomass to the RES as a whole. RES NAP assumes that in the year 2020, 3.3 TWh of electricity will be produced by combustion of solid biomass, and 2.87 TWh of electricity from agricultural biogas stations. The share of biomass exceeds $50 \%$ of the total expected production of electricity from RES in 2020 (11.7 TWh). There is also a significant increase in the share of biomass in PES as a whole, from around 76.4 PJ at present to around 122 PJ in 2020. Especially the use of biomass in biogas stations rises multiplicatively (from 2 PJ in 2009 to $17 \mathrm{PJ}$ in 2020) ${ }^{2)}$.

At present, mainly the residual and waste biomass is used for energy purposes in the Czech Republic. Only a small proportion of the biomass is represented by purposely grown biomass. At present (the last known statistic data are for 2010), from the total electricity production based on solid biomass combustion (1.49 TWh), only around 17\% is produced from purposely grown biomass. The production of electricity in biogas stations utilizing purposely grown biomass (mainly corn) is gradually rising ${ }^{3)}$.

Sources of residual and waste biomass, which would 
be suitable for energy purposes, are getting rapidly depleted and the expected development of the use of biomass is not possible without the purposeful growing of biomass on agricultural land. The expected increase in the use of biomass according to RES NAP between 2009 and 2020 is estimated at about 45 PJ. Assuming that two thirds of this increase will have to be covered by biomass from agricultural land; this indicates the need for growing biomass for energy purposes (without liquid biofuels) in the area of around 200,000 ha ${ }^{4}$.

Massive development of growing biomass for energy purposes requires enough information for decision-making of the businesses engaged both in the cultivation of biomass and its use. Investments in energy facilities for electricity and/or heat production are characterized by a high share of investment costs in the total costs. Investors consider not only the availability and security of fuel (biomass) but also a possible development of the fuel (biomass) price. The current market of biomass is largely defined by residual and waste biomass and has to the significant extent only the regional character. The current biomass prices range significantly depending on kind of biomass, region and offered value and they do not offer the proper price signals about possible future biomass price assuming the massive utilization of agriculture land for its production ${ }^{5)}$.

In general, it is possible to look at the price of any commodity from the view of at least two different parties whose interests are in contradiction. An investor in any project is reasonably trying to earn as much as possible, but always at least as much as he would have in the alternative investment options (in respect of the risk of the given type of projects). On the contrary, whoever wants to buy the product, wants to pay as little as possible, respectively, pay for the product up as much as they would pay for alternative supplies in the market with the commodity. When deciding on their business plans, both sides are trying to predict the course of prices in the market of the commodity; in this case the price of biomass ${ }^{6)}$.

When estimating the future price of biomass, respectively each of its forms, number of factors plays a role. The relationship between demand and supply in the relevant market is crucial to the price of biomass. However, it is possible to estimate the future cost of biomass based on economic models that simulate the processes necessary to obtain the required form of biomass and reflect the investor's expectations of the capital appreciation. We work here with the assumption that the outputs of such models represent the so-called long-term marginal cost. This means that provided a long-term demand for biomass (at a certain level), the price of biomass or its form will stabilize in the long term, at a level that ensures coverage of all expenses and the required capital appreciation.

Several different kinds of energy crop were tested for the conditions of the Czech Republic - e.g. Reed Canary Grass, Miscanthus, Sorrel Dock Hybrid, etc. Miscanthus, based on experiments on research fields (see chapter 2.3), has been selected as one of the promising kind of energy crop on agriculture land in the climate and soil conditions of the Czech Republic. Some major Czech district heating companies, e.g. Plzenská teplárenská, a.s., even began to test Miscanthus growing on pilot plantations.

The goal of the paper is an economic evaluation of Miscanthus growing for energy use - combustion (spring harvest) and calculation of biomass price using the economic model of Miscanthus growing. The economic model includes all the necessary processes that are needed for growing of Miscanthus and reflects current and the expected business conditions in the Czech Republic for this kind of business.

\section{Materials and methods}

\subsection{Estimation of biomass cost and minimum price calcula-} tion

The economic models are needed when evaluating the economic effectiveness of proposed project with lifetime longer than one year. In accordance with economic theory, the private investors seek to maximize the economic effects resulting from implementation of the project ${ }^{7}$. Net Present Value (NPV) criterion is the basic criterion for investor's decision making whether to accept or to reject given project. When NPV value for given project is higher than zero, investor gets higher rate of return on invested capital compared with the other investment opportunity. NPV equal to zero thus defines the limit to accept the evaluated project. But NPV calculation can be also done in reverse logic. The price of production (e.g. of planted biomass on agriculture field) is taken not as the input to the production, but as the resulting quantity of calculation using "limit to accept" NPV value (NPV=0) as the binding condition. This approach leads to the calculation of the socalled minimum price of production which is the bottom limit of (biomass) price from investor's point of view. Resulting from the logic of its calculation minimum price is needed specific price (at least) to assure (at least) the required rate of return on the capital invested for the investor. This approach is generally applicable to a wide range of economic tasks aimed at finding such specific price which ensure (required or regulated) rate of return on capital invested from the investor' s point of view, e.g. calculation of feed-in tariffs for power generated using RES. 
NVP of given project is the discounted sum of project cash flows during the project evaluation time. The general formula for NPV calculation is:

$$
N P V=\sum_{t=1}^{T_{i f}} C F_{t} \cdot\left(1+r_{n}\right)^{-t}=\sum_{t=1}^{T_{i f}}\left(R_{t}-E_{t}\right) \cdot\left(1+r_{n}\right)^{-t}
$$

Where

$T_{\text {lf }} \cdots$ project evaluation time - project lifetime period [years]

$r_{n} \quad \cdots$ nominal discount[-]

$t \quad \cdots \mathrm{t}$-th year of the evaluation period [-]

$C F_{t} \cdots$ cash flow in the year $t$ [EUR]

$R_{t} \cdots$ project revenues in $\mathrm{t}$-th year of the evaluation period [EUR]

$E_{t} \cdots$ project expenditures in $\mathrm{t}$-th year of the evaluation period [EUR]

Project expenditures include all the expenditures as sociated with the project - expenditures related to the plantation establishment, operational expenditures incl. paid taxes and expenditures of the plantation liquidation.

Assuming the above mention logic of the minimum price of production calculation (using NPV $=0$ as the binding condition) equation (1) can be expressed as the balance of the current value of project expenditures and current value of project revenues where revenues are calculated as the product of the minimum price and quantity produced:

$$
\sum_{t=1}^{T_{i f}}\left(p_{\min , t} \cdot Q_{t}+S_{t}\right) \cdot\left(1+r_{n}\right)^{-t}=\sum_{t=1}^{T_{i f}} E_{t} \cdot\left(1+r_{n}\right)^{-t}
$$

Where

$$
\begin{array}{lll}
p_{\text {min, },} & \cdots & \text { means the minimum price of production } \\
& & (\text { EUR/GJ) } \\
Q_{t} & \cdots & \text { quantity produced in the year } t(G J) \\
S_{t} & \cdots & \text { subsidy in the year } t(E U R)
\end{array}
$$

Note that expression of minimum biomass price in EUR/GJ eliminates possible misinterpretation of its value resulting from the assumption of wrong moisture content. Expression of fuel prices in EUR/GJ is widely use in energy branch and gives chance for simple and direct comparison of the different fuel prices.

Calculation of the minimum price which offers good price signals for the decision makers should reflect all the real business condition, e.g. inclusion of inflation. It means that minimum price in the year $t$ can be expressed as the minimum price in the project starting year $\left(\mathrm{p}_{\mathrm{min}, 1}\right)$ and the price escalation:

$p_{\min , t}=p_{\min , 1} \cdot(1+i)^{t}$

Where

$i \cdots$ means average expected inflation $[-]$

Using formula (2) and (3) minimum price of produc- tion (i.e. minimum price of produced biomass) can be expressed as follows:

$$
p_{\min , 1}=\frac{\sum_{t=1}^{T_{\text {Tf }}}\left(E_{t}-S_{t}\right) \cdot\left(1+r_{n}\right)^{-t}}{\sum_{t=1}^{T_{t i}} Q_{t}\left(1+r_{n}\right)^{-t} \cdot(1+i)^{t}}
$$

Energy crop, like Miscanthus, Reed Canary Grass etc. is characterized with the lifetime period 10-15 years. Some of the expenditures occur only one time during the lifetime period (plantation establishment, plantation liquidation), some other occur periodically (e.g. fertilization in 3 years cycle) and the remaining expenditures occur annually (harvest, overheads, etc.). Similarly the production of biomass cannot be assumed as the constant during the whole lifetime period - e.g at the beginning of plantation lifetime one can expect lower biomass production compared with the other years, etc. Short rotation coppice plantations have similar profile of revenues and expenditures - despite the fact of typically 3-5 years rotation and the longer project lifetime compared with perennials (20-25 years for SRC) the same methodology is applicable for the project economic valuation and the biomass cost/price calculation.

The attitude of the authors of conventional research to the economic evaluation of biomass projects with morethan-one-year lifetime and to the biomass price or cost calculation can be divided into following groups:

- Simple calculation of specific cost (expenditures) assuming "typical productive" year with the typical cost/expenditures and biomass yield. Initial costs of plantation establishment are allocated to the typical productive year as the simple ratio of initial cost and the lifetime period ${ }^{19)}$.

- NPV calculation using different scenarios of biomass price plus calculation of average (typical) cost per hectare assuming no time value of money ${ }^{20)}$.

- NPV approach including full opportunity cost approach (see later) and calculation of annual equivalent biomass cost as the product of NPV and annuity factor ${ }^{21}$.

- NPV approach including full opportunity cost approach and calculation of specific cost as the ratio of discounted project cost (in GJ) and discounted biomass yields ${ }^{22}$.

Despite the fact the application of the NPV approach is widely used for the economic evaluation of biomass project effectiveness and biomass price/cost calculation the significant differences exist between the authors (see above). First three above mentioned methodologies should be, according to the meaning of the authors, taken only as the simplified and approximate calculation. Exclusion of time value of money leads to the overestimation of the weight of the future projects years against the initial project years - typical example here is the simple allocation of the plantation establishment cost to the cost of biomass as the ratio of 
establishment cost and the project lifetime. Application of annuity factor to calculate specific biomass cost neglects the reality of business condition, i.e. inflation. Calculation of specific biomass cost as the product of project cost (expenditures) NPV and the annuity factor results in the constant value of biomass price for the whole project lifetime. Assuming general existence of inflation (and the necessity to include the inflation into individual cost item projection during the project lifetime) this approach leads to the overestimation of biomass cost/price at the beginning of the projects lifetime and consequently to the underestimation of the biomass cost/price in the end of the project lifetime. Approach applied by the authors in this article is comparable with last above mentioned approach. Only this approach, according to the meaning of the authors, fully respects the context of the biomass cost/price calculation.

Even in case that different authors use the same methodology, results of biomass cost/price calculation are not in many cases directly comparable. One of the critical inputs influencing NPV, and correspondingly also specific biomass cost/price value, is the discount rate used for NPV calculation or for the minimum price calculation. Authors utilize for calculation of the minimum price of biomass - as shown later - discount rate equal to $8.6 \%$. This value has been derived using (regulated) rate of return on capital invested 7\% (nominal) used for feed-in tariffs calculation in the Czech Republic (guaranteed purchase price for the electricity generated based on RES utilization) as the benchmark. Discount rate should, in general (according to the economic theory), reflect the opportunity cost of the investors (their other investment opportunities) ${ }^{7}$. Some authors simplify the discount rate setting to the application of general (average) interest rate applied to the farmers loans e.g. $5.5 \%{ }^{22}$. Even in case when authors highlight higher risk associated with the biomass production on agricultural land they usually utilize relatively low discount rate $(6-7 \%)^{23}$.

\subsection{Principles of economic model creation}

NPV calculation, and similarly also calculation of the minimum price of production are based on project cash flow simulation during the project lifetime. Project cash flow simulation needs creation of the economic model reflecting all the necessary activities to prepare, run and finish the given project. Cash flow simulation thus requires knowledge of both the investment costs of the project, and the estimated future operating costs, size of output and the price at which the production will be sold on the market with the commodity. Details to the methodology of economic evaluation and creation of economic models see Havlícková ${ }^{8) ~ 10) . ~}$
Using the experience of other authors one can formulate the main rules for the economic models creation: ${ }^{19) \sim 23)}$ - to reflect standard business condition of given kind of business (inflation, tax system, land rents, etc.),

- to include the whole project lifetime, including the preparatory and the terminal processes (e.g. obtaining all the necessary permissions, project preparation, plantation liquidation at the end of project lifetime, etc.),

- to include the market prices of all necessary inputs into the given projects,

- to determine the scope of project processes in physical units based on project processes analysis using e.g. time shots of activities (e.g. man and machines hours etc.),

- to determine the biomass yields (in GJ/hectare) using typical climate and soil conditions in the given area,

- to fully apply opportunity cost approach - all the project processes should be evaluated in monetary units using the market prices. Utilization of own machinery or own labour (or any other project input) should reflect typical market conditions of their hiring,

- to respect typical conditions of projects financing incl. available subsidies,

- to properly respect time value of money (i.e. rate of return concept) using adequate discount rate for cash flow discounting. Discount rate should reflect risk of business.

Areas of activities that are necessary for the implementation of projects aimed at the cultivation of biomass for energy purposes are:

- Preparatory and decision processes.

- Preparation of land.

- Provision of seeds, respectively of the planting materials.

- Plantation - the plantation running activities.

- Harvest of biomass, including transport to a central repository (logistic point).

- Restoration of land to its initial state.

- Overhead processes associated with the project implementation.

- Support for the particular form of biomass.

When developing the economic model of the project aimed at biomass production for energy purposes one can identify several different approaches to inclusion of project activities (processes). Some authors include into economic models only direct production activities related with the project incl. cost of land rent, fixed cost (overheads) are excluded ${ }^{20}$. Fixed cost (overheads) typically include administrative cost incl. paid services like book keeping, tax advisory, cost related with the company owners and their office etc. Some other authors allocate portion of overheads in EUR per hectare ${ }^{21}$. Different assumption on overheads 
allocation can cause differences in the calculation of biomass specific cost - overhead share in specific biomass cost (in case of energy crop) ranges between 10-18\% ${ }^{1415) 18) 21 \text {. }}$

The applied economic model is significantly affected by the temporal aspect of the investor's decision as to the targeted production of biomass, which is determined by the type and method of cultivation of biomass. From the time perspective, there are three basic types of economic models or approaches for estimating the future price of biomass: - Projects with a long time horizon, which amounts to twenty or more years. Examples are the short rotation coppice (SRC) plantations. These projects have quite the same character as normal business projects - the investor invests first and then the investment generates funds for the period of its lifetime.

- Projects with a medium time horizon, where the life cycle of the project is more than one year but less than in case of SCR plantations - typically it will be about 5-10 years for multi-annual energy crops.

- Projects with the time horizon of one year, in which the entire project life cycle lapses. Examples here are the oneyear energy crops, or also the conventional crops that are utilized for energy purposes in the time.

The time horizon of the project determines the period in which it is not possible to change the original decision on the project implementation, respectively where the change would mean significant losses for the investor. In the first two cases, comprehensive economic models need to be developed that will model the processes in each year.

In the third case, in principle, it is possible to simplify the task to a one-year time horizon, and derive the cost of biomass from the expenditure in this timeframe. In practice, however, this is often not possible - the producer e.g. enters into a long-term contract on the supply of biomass with specified parameters, respectively acquires special machinery, for which he/she has no other use, etc. Then also in this case it is necessary to create a multi-year economic model.

One factor that differentiates between the above three groups of energy biomass is the business risk, which is different in each of these groups. The biggest risk is in the first case when the investor gives money to the establishment of plantation, but he will start to receive revenues only after a certain time. There are significant risks such as extreme weather, which can significantly affect the profitability of plantations. At the same time the investor has only a limited ability to respond to any fluctuations in the biomass market (price drop). Conversely, in case of oneyear energy crops, the investor has the opportunity each year to consider the plan and potentially revalue its decision. Additionally, in case of extreme weather the investor risks write-off of substantially smaller costs, which would have to be spent on plantation.

\subsection{Data collection for the Miscanthus plantation economic model}

Data from the Miscanthus experimental plantations gathered within the research projects run by the Silva Tarouca Research Institute for Landscape and Ornamental Gardening and the Crop Research Institute, were primarily used for collecting input data. These plantations were established to test clones and cultivars of energy crops for biomass production under the different climatic and soil conditions of the Czech Republic.

Our experimental data and data from the literature search ${ }^{1921) \sim 23)}$ were used to create typical yield curves of biomass from Miscanthus plantation. These curves were then used in the economic model.

Logic of data collection for the economic model of Miscanthus plantation and minimum price of biomass calculation is shown on Fig. 1.

The costs of individual processes of Miscanthus projects aimed at biomass production for energy purposes were derived from analyses of the physical extent of the individual processes and activities. Processes were evaluated in monetary values using market prices of the Czech Republic (year 2010). Overheads including service and ancillary costs were set to respect the principles of causality
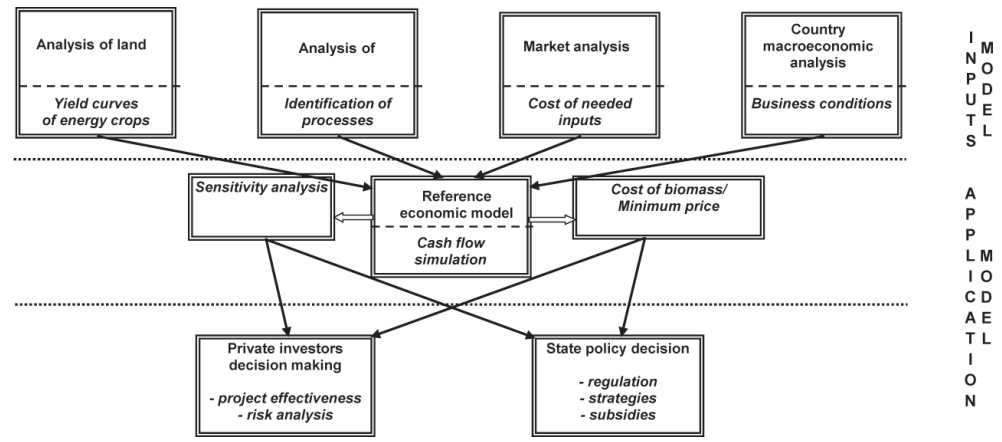

Fig. 1 Scheme of the economic model for the Miscanthus plantation 
and proportionality.

\subsection{Assumption used for the Miscanthus plantation eco- nomic model}

Miscanthus is a perennial plant with photosynthesis of type $\mathrm{C}_{4}$. Only the hybrid taxon $M . \times$ giganteus and species $M$. tinctorius, $M$. sinensis and $M$. sacchaflorus are used for the production of phytomass. In terms of growing without risks of invasive spread to the landscape, triploid taxon $M \times$ giganteus can be recommended. Blades of Miscanthus $\times$ giganteus are solid and lignifying, over 3 meters high and reaches full maturity after 3-4 years. Miscanthus places higher demands on climatic conditions than on soil. Miscanthus grows best on lighter structural soils, rather in warmer areas with a higher rainfall. Humic sandy soils with high water table and with little or no perennial weed infestation are recommended. In the fall, stubble plowing must be done with pulverization of crop residues and deep plowing. Before planting in the spring, seedbed preparation follows with soil hoeing to the depth of $10 \mathrm{~cm}$, mechanical and chemical weed killing.

Planting of Miscanthus is considered to be done using rhizomes at a length of 7-10 cm. Miscanthus is planted at a time when the soil temperature exceeds $10^{\circ} \mathrm{C}$, i.e. from mid May to mid July. The first year after planting, weeds are removed mechanically (e.g. by weeders) in the combination with herbicides. The second year does not count with the means for plant protection. For energy use (combustion), the model considers harvest after the winter as the problems with final drying will disappear. The model plans to harvest by a harvest lawn and a press for giant bales. Vegetation is considered to be disposed by digging the rhizomes, which in turn will be used for establishing new vegetation.

The economic model of Miscanthus crop for the production of biomass for direct combustion worked with four basic assumptions about biomass yields (in dry matter, bundled biomass) - See Table. 1.

These yields were based on the typical values for the conditions of the Czech Republic and respected the 30\% loss of biomass (in dry matter) due to the spring harvest - i.e. vegetation is left on land for the entire winter. The basic advantage is the very low water content in biomass, and

Table 1 Yield curves "Miscanthus - Spring Harvest"

\begin{tabular}{lcccc}
\hline Yield curve & K1 & K2 & K3 & K4 \\
\hline Biomass yield [t-dry/(ha year)] & 13 & 11 & 7 & 2.5 \\
\hline
\end{tabular}

Note: K1-K4 - average yields per year in tonnes of dry matter per hectare biomass does not have to finish-dried.

The model for Miscanthus is based on the following basic assumptions:

- The model has been developed for a 10 ha crop with the vegetation lifetime of 10 years. Spring harvest for direct combustion is assumed. Biomass is to be bundled (the socalled giant package)

- The vegetation was established in autumn, with the spring sowing in the next year, the 1st harvest in the following spring.

- Rhizomes are used for plantation establishment.

- A total of 10 harvests are considered.

- Cost of crop disposal is covered by the sale of rhizomes collected in the crop disposal process.

- Fertilization upon establishment of the vegetation: mineral fertilizers ${ }^{11) \sim 14)}$.

- Fertilization $\mathrm{N}$ during the lifetime of the crop is provided by ammonium nitrate sulphate fertilizer.

- The other basic assumptions included also the assumption that the executive processes are provided as an external service - such as harvesting, plowing, etc. The cost assessment of these processes uses market prices of these services.

- The harvesting included cutting and subsequent bundling. Transportation by tractor with a trailer was assumed to the central warehouse at a distance of $10 \mathrm{~km}$.

- After the useful life of the vegetation, rhizome was planned to be plowed and sold so as to establish new vegetation.

The model is designed so that individual processes are in terms of relation to the biomass yield, respectively the vegetation area, divided into processes with variable costs and processes with fixed costs. The model assumes that in the time $t=1$ (year 2009) an analysis and preparation of the project including a feasibility study were carried out. At the same time, it was assumed that a decision on the project is available so that in this year it was possible to prepare the land for the establishment of vegetation (autumn preparatory work). In the next year $t=2$ (2010) in the spring, vegetation establishment was expected.

The cost of renting the land is anticipated to be EUR $32 /$ (ha year). The cost of renting the land contributes about $5 \%$ to the total project costs ${ }^{\dagger 1}$. It was assumed that the project Miscanthus crop used a "relatively good" piece of land that does not need any extra measures - such as extensive weeding, extra fertilizing, etc. The vegetation was established by planting rhizome in the amount of 10,000 pcs/ha.

\footnotetext{
$\uparrow 1$ It is a share in the total discounted project cost.
} 
Miscanthus model inputs:

1. Fertilization:

- Plantation establishment: P,K: 164 EUR/hectare

- Plantation running: P,K - each two years: 131 EUR/ hectare, $\mathrm{N}$ - each year: 64 EUR/hectare

2. Plantation establishment:

- Land preparation: 264 EUR/hectare

- Rhizomes: 2400 EUR/hectare

3. Harvest (incl. transportation to the logistic point - at the distance $10 \mathrm{~km}$ ): $232 \mathrm{EUR} /$ hectare (biomass yield curve $11 \mathrm{t}$-dry/hectare)

4. Overheads: 30 EUR/hectare

5. Land rent: $32 \mathrm{EUR} /$ hectare

6. Discount rate (nominal): $8.7 \%$

7. Inflation rate: $2.5 \%$ (applied to the all cost items)

8. Corporate income tax rate: $19 \%$

9. SAPS value: 162,6 EUR/(ha year) - 2010 year value, Czech Rep.

Note that SAPS means Single Area Payment System which is the form of so called direct payments (i.e. subsidies) granted to the farmers within the EU Common Agriculture Policy. SAPS payment means subsidy directly granted to the farmer per each farmed hectare of the agriculture land (annual payment).

\section{Results}

\section{Economic efficiency of Miscanthus growing for direct com-} bustion

The minimum price of biomass is strongly influenced by the amount of subsidies. To analyze the impact of subsidies, calculations were made in two variants - without subsidies and with the SAPS subsidy (assuming the 2010 value constant over the whole project lifetime).

The minimum price of biomass for assumption of yield curves from 2.5 to $13.0 \mathrm{t}$-dry/(ha year), is then calculated according to the following Table 2.

The relatively very high values of the minimum biomass prices (compared e.g. with the crop of Reed canary grass) are caused by previously very high cost of crop es-

Table 2 The minimum price of biomass from Miscanthus vegetation

\begin{tabular}{cccc}
\hline & & \multicolumn{2}{c}{ EUR/GJ } \\
\hline & t-dry/(ha year) & $P_{\min }$ & $P_{\min , \text { SAPS }}$ \\
\hline K4 & 2.5 & 15.8 & 12.1 \\
K3 & 7.0 & 6.2 & 4.8 \\
K2 & 11.0 & 4.2 & 3.4 \\
K1 & 13.0 & 3.7 & 3.0 \\
\hline
\end{tabular}

Note: 1 EUR $=25.00$ CZK, exchange rate of the Czech National Bank, October 10, 2011 tablishment and in particular by the high purchase cost of rhizomes ${ }^{10) 14118 \text {. }}$

Minimum price (see chapter 2.1) is not constant during the project lifetime. According to the used methodology the constant inflation growth (here $2.5 \%$ ) is assumed during the project lifetime. Minimum price thus reflects the value for the first year of the project realization. Value of minimum price for the next years should be increased with the inflation. Calculated minimum price is comparable with the similar works dealing with the economy of biomass from Miscanthus plantation. Soldatos et al. presents results of average biomass cost calculation for the Miscanthus plantation (5 ha area) on the level $91 \mathrm{EUR} / \mathrm{t}$-dry for expected average biomass yield $13.1 \mathrm{t}$-dry/(ha year). Assuming app. $18 \mathrm{GJ} / \mathrm{t}$-dry (LHV) this leads to the $5.06 \mathrm{EUR} / \mathrm{GJ}$ (assuming no subsidy) ${ }^{21}$. Despite the utilization of similar methodology of biomass cost calculation the presented values of biomass cost are significantly higher than those presented here for the case of the Czech Republic. Value of specific biomass cost (that is comparable with here presented minimum price of biomass) is influenced by significantly higher expected cost of land rent. Cost of land rent is currently very low in the Czech Republic - according to the data presented by the Czech Statistical Office it ranges typically between 30-50 EUR/ha (year 2010 value). Soldatos et al. assumes land rent up to 500 EUR/ha (having app. 40\% weight in total cost of biomass). Assuming the value of land rent for the Czech Republic (and all the other cost in original values) calculation of biomass cost from Miscanthus plantation presented by Soldatos would lead to the value app. 3.5 EUR/GJ - fully comparable value with the results of calculation for the conditions of the Czech Republic.

Ericsson et al. presents similar results of biomass price calculation from Miscanthus plantation - app. 5.8-7 EUR/ GJ (in the conditions of UK and Ireland) ${ }^{23)}$.

\section{Discussion}

Relatively lower specific biomass cost (i.e. of minimum price of biomass) is currently caused esp. by low values of land rent in the Czech Republic. The typical values of land rent are much lower compared with EU15 countries and according to the currently available data presented by the Czech Statistical Office are in range 30-50 EUR/(ha year). This is caused by the unique situation in the agricultural land ownership (high number of small land owners, average area per one owner is just several hectares), high share of rented land (up to $85 \%$ of total land operated by the farmers), relatively high agriculture land area assumed as potentially not effectively utilizable for the classical agricultural production (up to 700,000-800,000 hectares) and 
last but not least prohibition of sell of land to the non citizens (expired in 2011) ${ }^{2}$.

The structure of expenditure on the Miscanthus vegetation (at present value) is documented in the following Fig. 2.

Miscanthus plantation is characterized with very high share of cost in the beginning of the project - as shown in Fig. 2 cost of rhizomes, cost of growth establishment and cost of land preparation together creates app.50\% of total project cost (in present value). Economic effectiveness of any project with such high value of initial cost is sensitive to the assumption on used discount rate. Minimum price of biomass is sensitive to discount rate in the similar way - see Fig. 3.

The price of biomass is, and probably will be even in the future, a very local issue; because the transportation at longer distances increases the final price of biomass relatively more than that of conventional fuels. The price level of biomass will always depend on the evolution of prices of inputs such as wages, energy costs, transportation, etc., and in our view, the differences in the prices of individual sites and various forms of biomass will remain relatively large in the future.

A relatively higher range of the minimum price in comparison with SRC plantations is due to the slightly higher dispersion in the projected yield curves K1 to K4

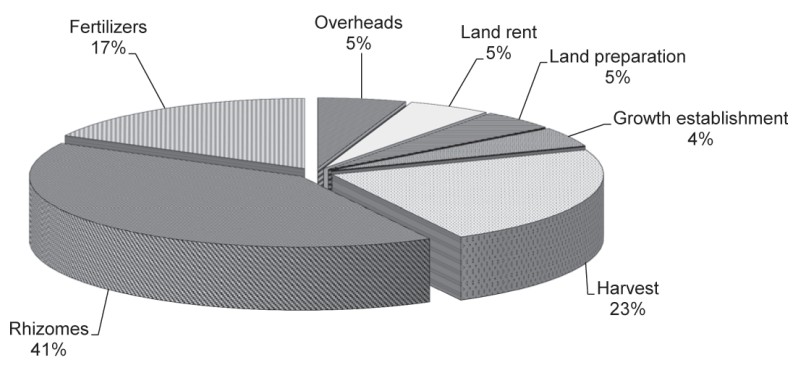

Fig. 2 Structure of specific (discounted) biomass cost for the Miscanthus plantation (spring harvest for combustion), yield curve $11 \mathrm{t}$-dry/(ha year)

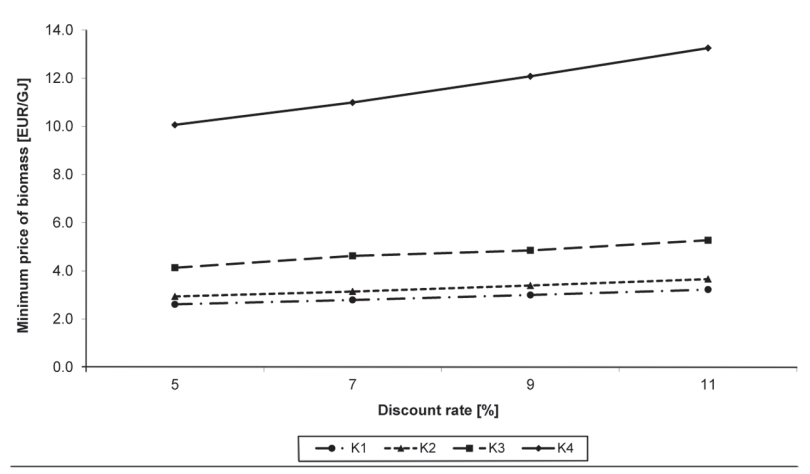

Fig. 3 Sensitivity analysis of minimum price of biomass from Miscanthus plantation on discount rate (minimum price assuming SAPS subsidy) and the different spending pattern ${ }^{10202) 21233}$. The yield curves are influenced by several factors such as the habitat, climate and time of harvest. For energy recovery (incineration), harvesting after winter prevails (February, March), since this eliminates the problems of final drying. At that time, the foreign data report the humidity of harvested phytomass around 22-38\%. According to our monitoring, Miscanthus harvested in late February in the third year after planting had an average humidity of $24 \%{ }^{15}$. The model calculates the harvest of Miscanthus phytomass after winter to have around 30\% loss of dry matter (due to significant defoliation and other losses). Southern Europe reports the loss of Miscanthus phytomass in spring harvest at 30-50\% compared to autumn harvest ${ }^{16}$. Thirty-percent loss by littering over the winter is also reported by Himken ${ }^{17)}$.

The minimum price of biomass derived from the criterion condition NPV $=0$ respects the effectiveness of the project from the investor's perspective. It is the lower limit price that the producer (investor) is willing to accept to have a guaranteed desired yield of the invested capital. The market price of biomass will then be influenced by other factors such as the potential economic yield from alternative ways of using the agricultural land, prices of substitutes (coal and other fossil fuels) after counting in the impact of emissions allowances for emissions of $\mathrm{CO}_{2}$. The minimum price of biomass estimated by modelling the economic efficiency of projects on biomass production thus cannot be mechanically mistaken for an estimate of future prices of biomass in the market without respecting the influence of these other factors. E.g. if the economic efficiency (per area unit) of growing the conventional agricultural crops is higher than the economic efficiency of purposely grown biomass for energy purposes, the biomass producer will require a higher or minimum price in order to balance the economic efficiency of both alternatives of use of agricultural land ${ }^{18}$.

Thanks to shortage in delivery of suitable domestic brown coal, esp. for small and middle size heating and cogeneration plants solid biomass plays more and more important role as the substitute of domestic coal esp. for heat production and delivery. According to currently available data from the Czech Heating Association fuel cost (specific price of coal) in heat production can be estimated on the level app. 2-3 EUR/GJ. Assuming the typical LHV of Czech brown coal used for heat production and delivery app. 15$16 \mathrm{MJ} / \mathrm{kg}$, app. 1.2-1.5 $\mathrm{t}-\mathrm{CO}_{2}$ released from burning of one ton of brown coal and price of one emission allowance (purchased in auctions since 2013) app. 20 EUR, the impact of emission allowances can be estimate in the range 
of 1.5-2 EUR/GJ. Inclusion of emission allowances into cost of fuel (cost of brown coal per GJ and cost of emission allowance per GJ) results in opening the space for biomass as the competitive substitute of the domestic brown coal used for heat production and delivery in the Czech Republic.

\section{Conclusions}

Economic models can serve as tools for analyzing the effectiveness of projects aimed at the purposeful cultivation of biomass for energy purposes and also to determine the lower price limit of the biomass species in the perspective of its producers, so that the biomass production was interesting for investors. The minimum price of biomass can be interpreted as a lower limit estimate of the biomass price in a longer period. This estimated price of biomass provides valuable information for investors' decisions about production and use of biomass as well as for decisions of state authorities in designing and correct adjustment of any support schemes for cultivation and use of biomass for energy purposes.

Economic evaluation of Miscanthus was carried out for the spring harvest term. The price of Miscanthus is intended for direct incineration and was calculated by the methodology of the minimum price and thus represents the minimum price at which a rational investor would sell their production to achieve the desired return on the invested capital. The price has been calculated for four yield curves (2.5-13.0 t-dry(ha year) and we can assume that the price (without subsidy) will vary within the range 3.7-15.8 EUR/ GJ. When considering the current level of SAPS subsidies, we can expect the price at 3-12.1 EUR/GJ depending on the yield. The relatively large price range is caused by a higher spread of the expected yield curves K1 to K4.

\section{Acknowledgements}

This study was performed in the frame of project no. MV-74990-8/OBV-2010, which was supported by the Czech Ministry of the Interior. We would also like to thank Mr. Zdenek Strasil, CSc., for providing the data and collaboration in developing the economic model.

\section{References}

1) Renewable energy sources in 2010 - results of the statistical survey. MIT 2010

2) National Action Plan of the Czech Republic for energy from renewable sources. MIT 2010

3) Knápek, J., Oslejsek, P., Havlícková, K., Economic effectiveness of energy grasses planted for biogas, (2011)

4) Havlícková, K. a kol, Analyza potenciálu biomasy v
Ceské republice. VUKOZ Pruhonice, p. 498, ISBN 97880-85116-72-4(2010)

5) Renewable energy sources in 2009 - results of the statistical survey. MIT 2009

6) Havlícková, K. a kol, Analyza potenciálu biomasy v Ceské republice. VUKOZ Pruhonice, p. 498, ISBN 97880-85116-72-4, (2010)

7) Brealey, J., Meyers, M., Teorie a praxe firemních financí, (Victoria Publishing, Praha), ISBN 80-85605-24-4, (1992)

8) Havlícková, K, Knápek, J., Vasícek, J., Weger, J., Biomasa obnovitelny zdroj energie - ekonomické a energetické aspekty - Acta Pruhoniciana 79, V?KOZ, Pruhonice, (2005)

9) Havlícková, K, Weger, J. a kol., Metodika analyzy potenciálu biomasu jako obnovitelného zdroje energie. Acta Pruhoniciana 83, VUKOZ, Pruhonice. ISBN 8085116-48-0, (2006)

10) Havlícková, K. a kol., Rostlinná biomasa jako zdroj energie. VUKOZ Pruhonice. ISBN 978-80-85116-65-6, (2008)

11) Mediavilla, V., Lehmann, J., Meister, E., Energiegras/ Feldholz - Energiegras, Jahresbericht 1993, Bundesamt für Energiewirtschaft, Bern, (1993)

12) Mediavilla, V., Lehmann, J., Meister, E., Stünzi, H., Serafin, F., Energiegras/Feldholz - Energiegras, Jahresbericht 1994, Bundesamt für Energiewirtschaft, Bern, (1994)

13) Mediavilla, V., Lehmann, J., Meister, E., Energiegras/ Feldholz - Energiegras, Jahresbericht 1995, Bundesamt für Energiewirtschaft, Bern, (1995)

14) Olsson, R., Production methods and costs for reed canary grass as an energy crops. In: Bioenergy Research Programme, Publication 2, Bioenergy 93 Conference, Finland, (1993)

15) Strasil, Z., Proceedings of the International Conference from 15th European Biomass Conference and Exhibition from Research to Market Deployment. Berlin, 7-11 May 2007, 824-827 (2007)

16) Lewandowski, I., Clifton-Brown, J. C., Scurlock, J. M. O., Huisman, W., Biomass and Bioenergy, 19 (4), 209-227 (2000)

17) Himken, M., Lammel, J., Neukirchen, D., CzypionkaKrause, U., Olfs, H. W., Plant and Soil, 189 (1), 117-126 (1997)

18) Knápek, J., Oslejsek, P., Havlícková, K., Economic effectiveness of energy grasses planted for biogas, (2011)

19) Fazio, S., Barbanti, L., Venturi, G., Energy and economic balances of different dedicated energy crops. In 17th European Biomass Conference \& Exhibition [CD-ROM]. Florencie: ETA - Florence, 2009, vol. 1, p. 299-301, ISBN 978-88-89407-57-3, (2009)

20) Valentine, J., Heaton, R., Randerson, P., Duller, Ch., The 
economics of short rotation coppice in the UK. In 16th European Biomass Conference \& Exhibition [CD-ROM]. Florencie: ETA - Florence, 2008, vol. 1, p. 527-528, ISBN 978-88-89407-58-1, (2008)

21) Soldatos, P. G., Lychnaras, V., Asimakis, D., Christou, M., Bee-biomass economic evaluation: A model for the economic analysis of energy crops production. In 2nd World Conference and technology Exhibition on Biomass for Energy, Industry and Climate Protection [CD-ROM]. Florencie: ETA - Florence, 2008, vol. 1, ISBN: 88-8940703-4, (2004)

22) Hilst, F., Dornburg, V., Faaij, A., Sanders, J., Elbersen, W.,
Turkenburg, W., Economic and energetic performance of energy crops: An analysis for the northern regions of the Netherlands. In 16th European Biomass Conference \& Exhibition [CD-ROM]. Florencie: ETA - Florence, 2008, vol. 1, p. 2585-2590, ISBN 978-88-89407-58-1, (2008)

23) Ericsson, K., Rosenqvist, H, Nilsson, L., Future energy crop production cost in the EU. In 15th European Biomass Conference \& Exhibition [CD-ROM]. Florencie: ETA - Florence, 2007, vol. 1, p. 2203-2207, ISBN 978-8889407-59-X, (2007) 